\title{
Metode Pembelajaran Penerjemahan
}

\author{
Oleh: Yoce Aliah Darma")
}

Abstrak: Keterampilan menerjemahkan adalah suatu keterampilan berbahasa yang menuntut penguasaan dua bahasa, misalnya bahasa Inggris sebagai Bahasa Sumber (BSu) dan bahasa Indonesia sebagai Bahasa Sasaran (BSa). Dalam dunia informasi masalah ini sangat penting, karena banyak informasi yang berasal dari sumber bacaan bahasa asing. Informasi dari bahasa asing ini dapat diterima dengan cara menerjemahkan dan biasanya dilakukan oleh penerjemah. Penerjemah ini yang harus menguasai bagaimana metode dan proses pemahaman dalam penerjemahan. Menurut Newmark untuk memahami suatu teks diperlukan penguasaan cara membaca umum (general reading), tujuannya untuk mendapatkan 'pesan pokok', dan cara membaca cermat (closer reading) untuk 'memahami kata-kata', baik dalam konteks teks, maupun di luar konteks, dalam arti apakah makna kata itu berupa arti teknis, gaya bahasa atau arti kiasan. Metode yang paling mudah digunakan adalah metode padanan kata yang dikemukakan oleh Catford, yaitu penerjemahan kata per kata (word by word translation), penerjemahan harfiah (literary translation), dan penerjemahan bebas (free translation).

Kata Kunci: membaca umum, membaca cermat, penerjemahan kata per kata, penerjemahan harfiah, dan penerjemahan bebas.

\section{Pendahuluan}

Proses pemahaman dalam pembelajaran penerjemahan sangat penting, karena tanpa pemahaman makna yang tepat, jelas, dan wajar dari teks bahasa sumber (BSu) yang dibaca tidak mungkin bisa menyatukan padanan makna tersebut ke dalam bahasa sasaran (BSa). Langkah-langkah yang perlu diperhatikan adalah: (a) Keterampilan membaca. Keterampilan ini perlu dilatih terutama dalam membaca wacana BSu dari berbagai ragam dan berbagai tingkat kesukaran. Keterampilan ini perlu dimotivasi untuk meningkatkan

*) Yoce Aliah Darma adalah dosen FPBS/PPS UPI 
pemahaman baik pemahaman literal maupun pemahaman apresiatif, karena itu perlu adanya program pembelajaran penerjemahan yang baik, baik dalam konsep maupun dalam pelaksanaannya. Peningkatan keterampilan membaca ini akan meningkatkan pula kemampuan memahami makna semantik, pragmatik, dan tekstual. (b) Keterampilan menulis. Pemahaman pesan dari teks bahasa sumber (BSu) misalnya bahasa Inggris belum cukup untuk menerjemahkan dengan baik ke dalam BSa misalnya bahasa Indonesia. Proses memahami teks BSu harus diimbangi dengan kemampuan berbahasa BSa. Penerjemah harus dapat mengungkap makna pesan $\mathrm{BSu}$ ke dalam BSa dengan baik dan benar, dalam arti dapat menggunakan kosakata (istilah) maupun struktur yang berterima sesuai konteks dan ragamnya. Penerjemah diharapkan dapat meningkatkan potensi untuk mencari padanan makna terjemahan yang tepat, jelas, dan wajar. Potensi ini hendaknya dilakukan secara terprogram untuk meminimalisasi aspek-aspek yang rawan akan kesalahan.

Tujuan pokok penerjemahan adalah mengalihkan makna dari satu teks ke teks lain. Untuk sampai pada tujuan itu diperlukan jalan, cara atau teknik untuk mencapainya. Newmark (1984) menyebut kegiatan ini metode, yang dalam arti sempit dapat saja disebut teori mengenai terjemahan. Dalam hal ini diperlukan metode terjemahan yang cocok untuk digunakan dalam menerjemahkan teks tertentu yang terkait dengan teori bahasa. Catford (1965) mengemukakan bahwa masalah utama dalam penerjemahan adalah pencarian padanan dalam $\mathrm{BSa}$, yang ciri serta keadaannya harus dijelaskan oleh suatu teori. Selanjutnya, Catford mengemukakan bahwa penerjemahan ada yang besifat rank bound (terikat pada tatarannya), dalam arti padanan BSa ada pada tataran. Istilah metode penerjemahan ini lebih popule dengan istilah word by word translation (penerjemahan kata per kata), literary translation (penerjemahan harfiah), dan free translation (penerjemahan bebas).

Keterampilan menerjemahkan perlu dilakukan dengan usaha mencoba dan meralat dan dilakukan terus menerus. Dengan pengalaman menerjemahkan yang banyak, maka penerjemah akan menemukan keterampilan berikut kiat menerjemahkan yang baik. Kelemahan latihan mencoba dan meralat ini adalah waktu, karena waktunya mungkin akan lama, karena itu perlu penge- 
tahuan tentang teori penerjemahan yang diperoleh dari pengalaman orang lain dan penelaahan para ahli, atau kalau perlu melakukan observasi ke lembaga-lembaga yang berkaitan dengan layanan penerjemahan. Penerjemahan adalah suatu bentuk komunikasi karena penerjemah berperan sebagai perantara untuk menyampaikan pesan BSu kepada masyarakat pembaca BSu. Komunikasi ini dapat dianggap sebagai suatu kegiatan yang menarik bila penerjemah bisa menampilkan hasil terjemahannya dibaca oleh orang lain, misalnya artikel terjemahan dimuat di media massa. Keberhasilan dalam kegiatan ini akan memberikan pengalaman berharga dan motivasi yang meningkat, serta percaya diri.

\section{Kajian Literatur dan Pembahasan}

\subsection{Penerjemahan}

Kata penerjemahan merupakan bentuk derivasi dari kata dasar terjemah (verba), dari kata tersebut terbentuk derivasi lain seperti menerjemahkan, terjemahan, dan penerjemah. Verba menerjemahkan berarti menyalin (memindahkan) dari suatu bahasa ke bahasa lain atau mengalihbahasakan. Nomina terjemahan berarti salinan bahasa, yaitu alih bahasa dari suatu bahasa ke bahasa lain. Derivasi penerjemahan berarti proses, perbuatan, cara menerjemahkan, dan pengalihbahasaan. Penerjemah berarti orang yang mengalihbahasakan atau juru terjemah. Nomina translation bermakna sebagai the act of translating; removel to another place; the rendering into another language; a version. Derivasi translating dapat berfungsi verba yang berarti menerjemahkan atau berfungsi sebagai nomina (gerund) yang mengandung arti proses penerjemahan.

Penerjemahan merupakan padanan dari kata translation. Translation adalah nomina dari verbal to translate. Catford (1965:20) mengatakan bahwa penerjemahan adalah "The replacement of textual material in one language by equivalent textual material in another language". Pengertian Catford ini cukup luas, karena mengandung dua ungkapan penting yang memerlukan penjelasan yaitu textual material (wacana) dan equivalent (padanan). Selanjutnya, Catford menyatakan bahwa penerjemahan biasa tidaklah seluruh wacana dialihkan ke dalam padanan bahasa sasaran. Sintaksis atau leksikon tidak dialihkan dengan pemberian padanan tetapi hanya dengan bentuk transference, 
sedangkan padanan merupakan istilah kunci dalam penerjemahan. Yang penting kita menemukan 'padanan terjemahan dalam bahasa sasaran'. Kata padan dan padanan adalah merupakan kata kunci.

Inti penerjemahan adalah melestarikan makna antara dua bahasa yang mencakup aspek semantis, pragmatis dan tekstual. Aspek semantis mengacu pada makna denotatif (reference), aspek pragmatis pada makna konotatif, dan aspek tekstual pada makna tekstual, yaitu pada bentuk wacana yang diproses melalui substansi, referensi, elipsis, dan anafora. Ketiga makna ini memperoleh padanan dalam wacana terjemahan yang memadai (House, 1977:30).

\subsection{Proses Penerjemahan}

Proses penerjemahan adalah rangkaian tindakan dalam usaha menerjemahkan, sehingga menghasilkan terjemahan. Selain itu proses penerjemahan merupakan tindakan penerjemah dalam usaha mengalihkan suatu wacana bahasa sumber (BSu) ke dalam wacana bahasa sasaran (BSa) dengan menggunakan pengetahuan, kemampuan, dan keterampilan. Usaha tersebut adalah mencari wacana padanan dalam bahasa sasaran. Katharine Barnwell (1984:13) mengungkap dua tahap penerjemahan: (a) analisis makna bahasa sumber, yang disebut eksegesis dan (b) mengungkap kembali makna setepat mungkin dalam bentuk bahasa sasaran yang wajar dan alamiah, yang disebut restrukturisasi.

Kedua tahapan ini bersifat umum yang memerlukan penjelasan lebih rinci, yaitu bagaimana menemukan makna dari bahasa sumber, dan kemampuan apa yang perlu dikuasai dalam hal ini. Kemudian bagaimana menyusun kembali pesan dan keterampilan apa yang perlu dikuasai. Proses penerjemahan ini dapat digambarkan sebagai berikut.

\section{Proses Penerjemahan}

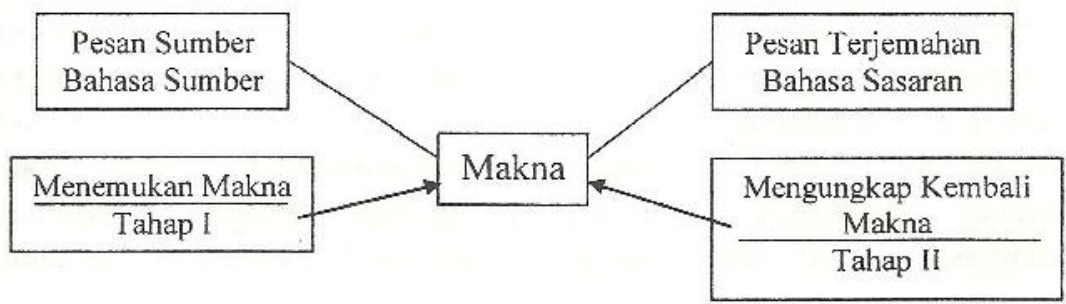


Dua tahap proses penerjemahan di atas lebih rinci diuraikan oleh Hatim dan Mason (1990), bahwa tugas penerjemah meliputi aspek (a) Pemahaman teks sumber, yaitu mengurai teks, baik tata bahasa maupun kosakata, menelusuri pengetahuan khusus, dan menelusuri makna yang dimaksudkan, (b) Pengalihan makna, yaitu menggunakan makna leksikal, menggunakan makna gramatikal, dan menggunakan makna retoris termasuk makna tersirat, (c) Penilaian teks sasaran, yaitu keterbacaan, penyerasian dengan konvensi umum dan wacana, dan menimbang kememadaian terjemahan untuk tujuan khusus.

Penerjemahan merupakan the transposition of the text written in a source language into a target language (Weber, 1984). Selanjutnya menurut Weber, teks terjemahan harus betul-betul cermat dalam makna, mengandung semua nuansa makna teks asli dan harus ditulis dalam bahasa yang jelas serta enak dibaca, sehingga dapat dipahami dengan mudah oleh pembaca. Oleh karena itu aspek tanda baca, ejaan, dan tata bahasa tidak boleh salah. Selain itu penerjemah hendaknya memiliki kamus-kamus dan bahan-bahan rujukan dalam kedua bahasa yàng digunakan. Istilah penerjemahan menggunakan bahasa tulis dan istilah interpretasi menggunakan penerjemahan bahasa lisan. Orang yang menerjemahkan bahasa tulis disebut translator (penerjemah) dan orang yang menerjemahkan bahasa lisan disebut interpreter.

Proses penerjemahan menuntut bukan hanya menguasai dua bahasa, kedwibahasaan juga merupakan salah satu prasyarat. Berbeda dengan interpreter penerjemah menggunakan pengetahuan bahasanya untuk membantu pembaca dan penulis dapat berkomunikasi dalam bahasa tulis. Penerjemah tidak bebas mengemukakan gagasannya dengan kata lain penerjemah tidak dapat mengungkapkan gagasan yang dia peroleh dari bahasa tulisan menurut kemauannya sendiri. Teks asli memberi pembatasan kualitatif dan kuantitatif terhadap penerjemah. Pembatasan kualitatif berarti makna harus diungkap kembali dan pembatasan kuantitatif bentuk harus dihormati. Tugas penerjemah bukan menjelaskan, tetapi memformulasikan kembali. Perbedaan antara dwibahasawan dan penerjemah ialah dwibahasawan tulen mampu mengungkapkan dirinya secara sepenuhnya dalam bahasa kedua, sedangkan penerjemah hanya perlu mamahami. Penerjemah tidak perlu menjadi 
dwibahasawan tulen, karena dia bekerja dengan bahasa tulisan, jadi kemampuan berbicara dalam bahasa kedua dengan lancar tidak diperlukan.

Persyaratan yang dituntut dari seorang penerjemah tidak selalu harus menguasai semua keterampilan dalam dua bahasa secara sama atau setingkat. Yang dituntut adalah kemampuan reseptif(kemampuan membaca dalam bahasa sumber) dan kemampuan produktif(kemampuan menulis dalam bahasa sasaran).

\subsection{Pemahaman Dalam Penerjemahan}

Dalam proses penerjemahan, keterampilan berbahasa sangat penting, karena pemahaman dalam membaca dan mengungkap pesan dari bahasa sumber ke dalam bahasa sasaran didasari oleh keterampilan berbahasa tersebut.

Seorang penerjemah harus dapat memahami bahan atau wacana yang akan diterjemahkan. Pemahaman seseorang terhadap suatu teks dipengaruhi oleh berbagai faktor seperti pengetahuan kebahasaan yang menyangkut penguasaan struktur, kosa kata, makna, dan sistem baca-tulis, jenis bahan bacaan, dan tingkat kesulitan bahan bacaan, baik dalam penggunaan bahasanya atau materi bahan bacaannya. Dalam menerjemahkan suatu wacana, pertama penerjemah harus membaca wacana sumber sebelum mengalihkannya ke dalam bahasa penerima. Tujuannya untuk mengetahui isi teks dan menganalisisnya dengan cara pandang penerjemah yang berbeda dengan cara pandang linguis atau ahli sastra.

Menurut Newmark (1988:11) memahami suatu teks menuntut tidak hanya cara membaca umum (general reading), tetapi juga cara membaca cermat (closer reading). General reading bertujuan untuk mendapatkan makna, pesan umum atau pesan pokok, closer reading untuk memahami kata-kata, baik dalam konteks teks maupun di luar konteks. Misalnya, suatu kata hendaknya dilihat dari arti teknis, gaya bahasa, atau arti kiasan. Selanjutnya, Newmark mengatakan bahwa dalam proses memahami suatu teks yang akan diterjemahkan perlu ditentukan khalayak pembaca (readership) bahasa sumber terjemahan dan khalayak pembaca hasil terjemahan. Dalam hal ini penerjemah menilai tingkat pendidikan, kelas masyarakat, umur dan jenis kelamin, langkah ini penting untuk menentukan tingkat keformalan, keumuman dan kekhususan, dan nada emosi yang harus diungkapkan ketika menerjemahkan 
suatu teks. Demikian juga, saat membaca penerjemah harus mencermati tingkat gaya bahasa, seperti ragam resmi, formal, netral, informal dan akrab.

Delisle (1980:53) mengungkap bahwa proses memperoleh padanan dalam penerjemahan ada tiga tahap, yaitu pemahaman, reformulasi, dan verifikasi.

\section{a. Pemahaman}

Pemahaman teks sebagai langkah awal proses penerjemahan adalah usaha penerjemah untuk memastikan apa yang dimaksudkan oleh penulis. Dalam hal ini kita tidak dapat menangkap makna dengan sekedar membaca, tetapi perlu membaca tanda-tanda grafis atau memaknai bunyi-bunyi yang disimbolkan oleh tanda-tanda tadi tanpa memahaminya. Tindakan persepsi yang bersifat fisik ini harus diikuti tindakan mental yang disebut analisis interpretatif.

Penerjemah tidak hanya melakukan analisis leksikal dan gramatikal, tetapi mengalihkan setiap tanda pernyataan asal ke dalam bahasa penerima dengan padanan yang telah dipilih. Pengalihkodean (transcoding) ini akan menghasilkan ungkapan yang secara gramatikal benar, tetapi belum tentu secara semantis. Ini berarti penerjemah membatasi diri pada pemahaman signifieds (konsep) sehingga padanan yang dihasilkan didasarkan pada interpretasi yang tidak lengkap.

Tahap analisis, penerjemah harus menentukan makna konseptual yang tepat dengan menggunakan konteks inferensial. Tujuannya adalah untuk menemukan signifikansi tanda linguistik suatu bahasa, apa yang dimaksudkan oleh tanda-tanda sebagai bagian dari suatu pesan. Dalam kaitan ini penerjemahan merupakan pengungkapan kembali konsep atau gagasan bukannya tanda. Makna diartikan sebagai sintesis yang terbentuk dengan adanya pertautan antara rujukan struktural dan situasional. Menurut Delisle (1980:60) interpretasi merupakan penemuan perkiraan terhadap hubungan antara referent (objek konkret atau konsep abstrak) dan tanda lingistik dalam suatu pesan. Oleh karena itu, kata-kata dan kalimatkalimat selalu terbuka bagi interpretasi menurut parameter situasional yang menentukan situasi komunikatif. Selanjutnya Delisle mengatakan bahwa untuk memahami suatu ujaran kita harus mengeluarkan konsep dari tanda (signifiers) dan menghubungkannya dengan pengetahuan linguistik. Bahasa dianggap sebagai salah satu komponen pesan. 
Pemahaman terhadap ide atau objek kongkret sebagai suatu signifikansi dikodifikasi dalam suatu sistem bahasa dan bersifat statis, sedangkan makna (meaning) tidak dikodifikasi dan cenderung dinamis.

\section{b. Reformulasi Gagasan}

Reformulasi adalah reverbalisasi konsep-konsep dengan memakai bahasa lain. Hal ini merupakan proses mental, sangat rumit untuk dianalisis. Ide-ide yang diidentifikasi melalui analisis interpretasi membentuk rangkaian berpikir analogis dalam otak penerjemah. Tidak mudah mengungkap kerja otak manusia sebagai komputer yang sangat mengagumkan, kerja otak lebih rumit daripada mesin berpikir buatan manusia, otak dapat memformulasikan ide-ide atau gagasangagasan. Menurut Delisle pencarian padanan dalam penerjemahan jauh lebih rumit daripada usaha sederhana ingatan penerjemah dalam membaca sepintas (scan) suatu kamus internal untuk mencari kata-kata yang sesuai dengan konsep yang akan disusun kembali. Reformulasi bukan sekedar penamaan konsep, tetapi merupakan suatu usaha yang menggunakan kecerdasan yang menurut Piaget merupakan serangkaian living and acting operations, meskipun setiap operasi tidak disadari penerjemah.
Memformulasikan kembali gagasan-gagasan harus dikerjakan penerjemah terus-menerus secara bolak-balik antara memahami makna dan mencari ungkapan serta bentuk bahasa untuk mengungkapkan kembali makna itu. Akhirnya kerja bolak-balik ini akan berhenti bila padanan yang memuaskan ditemukan. Dalam proses memahami makna, penerjemah berpikir dengan menggunakan analogi, menggali sumbersumber ungkapan dalam bahasa lain melalui serangkaian asosiasi, deduksi, atau inferensi. Penerjemah bekerja dalam beberapa tahapan yang tidak selalu merupakan garis lurus, seperti kata Piaget, otak manusia selalu bebas melakukan gerak berputar dan bekerja dengan asosiasi. Selanjutnya, kompetensi penerjemah banyak bergantung pada kemampuan deduktif dan asosiatif.

Untuk mendapatkan padanan kata atau ungkapan, penerjemah dengan analogi menggali sumbersumber bahasa sasaran untuk mencari tanda-tanda linguistik (linguistic signs) yang mampu mengungkap gagasan dari kata atau ungkapan itu. Sebagai salah satu cara, sekali suatu makna didapatkan, makna itu diformulasikan kembali dalam bentuk gagasan-gagasan dan bukan kata-kata. Secara sadar dan tak sadar, 
penerjemah mencari-cari formulasi yang tepat. Informasi dipanggil dan dibangkitkan dari ingatan. Dalam proses mencari ini, setiap kali penerjemah menolak kemungkinan solusi yang tak memuaskan, dia memberikan pertimbangan tentang kecocokan bentuk isinya. Dalam proses berpikir kreatif ini, penerjemah melakukan proses kognitif yang menggunakan pengetahuan umum, semua informasi linguistik, dan ensiklopedi yang tersimpan di otak. Sejumlah padanan sifatnya tetap. Makin banyak bentuk-bentuk baku dalam suatu bidang, makin sedikit kebebasan penerjemah dalam mengungkap gagasan-gagasan dalam bidang tersebut. Oleh karena itu, penerjemah harus menyesuaikan dengan ungkapan yang sudah diterima, misalnya 'wise words' diterjemahkan menjadi 'kata-kata mutiara', bukan 'kata-kata bijaksana'.

\section{c. Verifikasi}

Tahap ketiga dari proses kognitif penerjemahan adalah verifikasi yang bertujuan untuk memastikan kecermatan solusi terjemahan. Hal ini dilakukan dengan menilai apakah padanan yang diambil dapat mengalihkan seluruh makna ujaran bahasa sumber (BSu) dengan baik?
Verifikasi selalu merupakan fungsi interpretasi dan verikasi itu sendiri adalah interpretasi. Verifikasi juga merupakan interpretasi kedua. Interpretasi pertama terjadi saat konsep-konsep telah dipahami dan sebelum diungkapkan kembali, maksudnya untuk mengidentikasi gagasan dan pesan. Interpretasi kedua terjadi setelah pengungkapan kembali dan sebelum pemilihan versi akhir. Hal ini dimaksudkan untuk menentukan apakah ungkapan yang dipilih sebagai solusi sementara secara cermat mengungkapkan gagasan-gagasan dan pesan itu? Pemeriksaan kualitas terjemahan merupakan proses nalar. Jadi dalam menerjemahkan terdapat dua interpretasi, yaitu (1) Interpretasi yang didasarkan atas tanda-tanda teks bahasa sumber (BSu) dan (2) Interpretasi yang didasarkan atas tanda-tanda teks bahasa sasaran (BSa) setelah dimisalkan sebagai solusi sementara atau kemungkinan padanannya.

Di bawah ini digambarkan heuristik penerjemahan menurut Delisle (1980:69 


\section{Heuristik Penerjemahan (Delisle)}

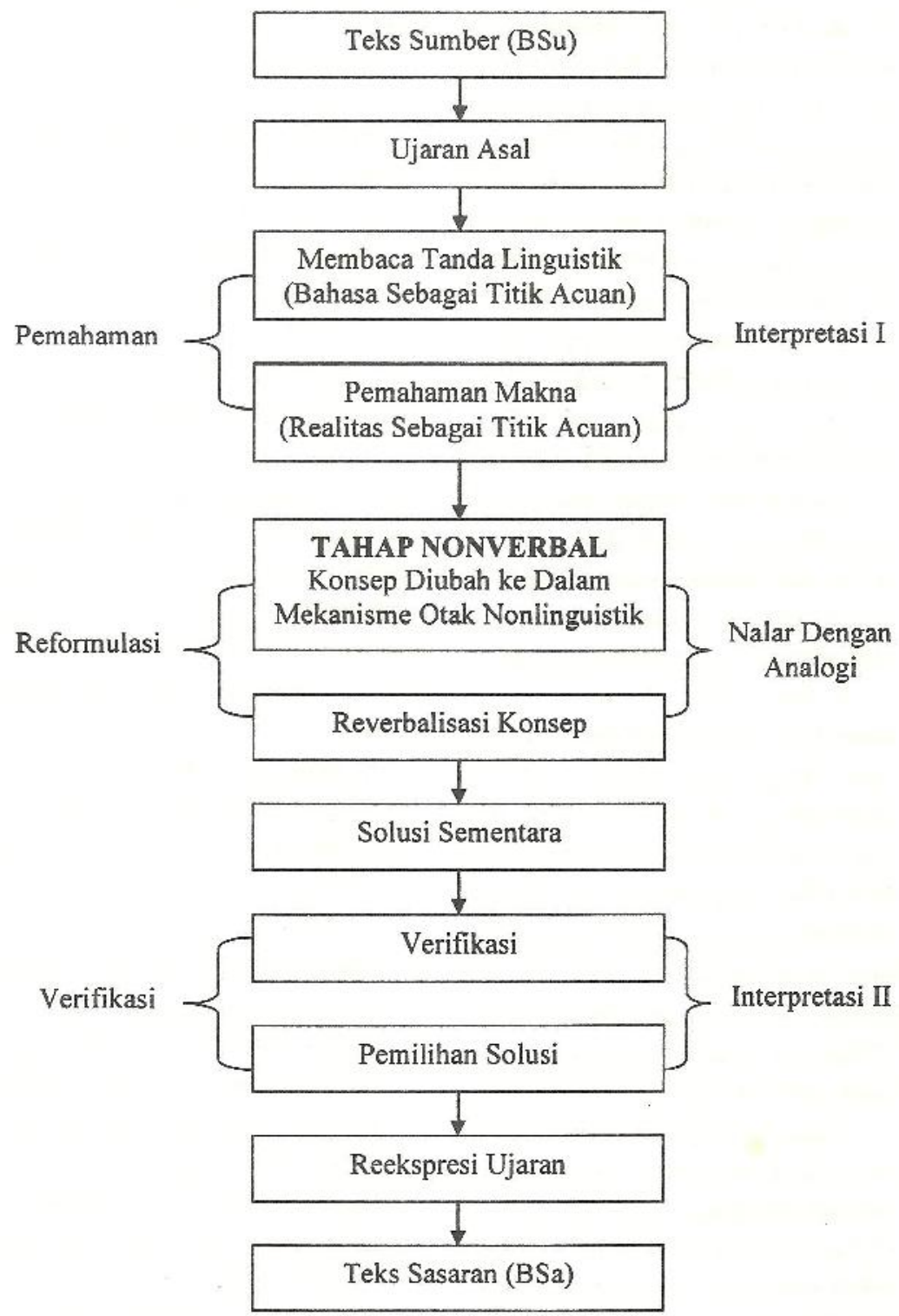




\subsection{Metode Penerjemahan}

Tujuan pokok penerjemahan adalah mengalihkan suatu teks sumber ke dalam teks bahasa lain, untuk sampai pada tujuan itu kita menentukan cara dan teknik untuk mencapainya. Newmark (1988) menyebutkan kegiatan ini sebagai metode, sedangkan penulis lain menyebutkannya teknik, prosedur, atau strategi. Tugas penerjemah tidaklah mudah. Menurut Newmark penerjemah harus bekerja dalam empat peringkat, yaitu (a) Penerjemahan sebagai sains, yang menuntut pengetahuan dan verifikasi fakta dan bahasa yang memeriksanya, (b) Penerjemahan sebagai keterampilan yang menuntut bahasa yang wajar dan penggunaanya diterima, (c) Penerjemahan sebagai seni yang membedakan adanya tulisan yang baik dan tidak baik, yang menunjukkan tingkat kreatifitas, intuisi dan inspirasi, dan (d) Penterjemahan adalah masalah rasa, dalam kali ini argumentasi terhenti dan terasa adanya preferensi dan keragaman terjemahan, yang merupakan cerminan perbedaan individu.

Teori penerjemahan berpendapat bagi penerjemah dalam rangka mengaitkan antara teori dan praktik sehingga penerjemah dapat menggunakan suatu teori dalam memecahkan masalah-masalah penerjemahan.
Dalam hal ini Catford (1965) menyatakan:

The central problem of translation practice is that of finding target language (TL) translation equivalents. A central taks of translation theory is that of defining the nature and condition of translation equivalen.

Bagi Catford masalah utama praktik penerjemahan adalah pencarian padanan dalam BSa yang ciri serta keadaannya harus dijelaskan oleh suatu teori untuk mendapatkan padanan (equitment) dalam bahasa sasaran (BSa) Catford (1965) membagi penerjemahan berdasarkan rentang (extent), tingkatan (level), dan tataran (ranks).

a. penerjemahan bersadarkan rentang (extent), yaitu (1) penerjemahan penuh. Dalam penerjemahan ini seluruh teks diolah melalui proses penerjemahan; setiap bagian teks BSa diganti dengan materi teks BSa. (2) Penerjemahan parsial. Pada penerjemahan ini suatu bagian teks BSa dibiarkan dalam keadaan tidak diterjemahkan. Bagianbagian itu hanya dialihkan dan dimasukkan ke dalam teks BSa, Seperti dalam penerjemahan hanya sastra ada bagian yang 
dianggap tak bisa diterjemahkan, atau disengaja untuk memberi warna lokal.

b. penerjemahan berdasarkan level bahasa, yaitu (1) penerjemahan menyeluruh (Total). Penerjemahan ini merupakan pengalihan tata bahasa dan kosakata bahasa sumber (BSu) dengan padanan tata bahasa sasaran (BSa) yang disertai dengan pengalihan fonologi atau grafologi, isu dengan fonologi atau fonologi BSa (yang bukan padanannya). (2) penerjemahan terbatas. Penerjemahan ini dimaksudkan untuk pengalihan makna tekstual $\mathrm{BSu}$ dengan materi tekstual padanannya pada satu tataran, umpamanya terjemahan yang dilakukan pada tataran fonologi, grafologi, tata bahasa dan kosakata

c. penerjemahan berdasarkan tataran (ranks). Dalam hierarki berdasarkan tata bahasa sebagai landasan penyusunan penerjemahan, unit tata bahasa yang akan dicarikan padanannya mungkin berubah- ubah, kalimat ke kalimat, frase ke frase, kata ke kata dsb. Dalam hal ini terjemahan ada yang bersifat rank bound (terikat pada tatarannya), yaitu padanan BSa ada pada tataran yang sama, umpamanya tahap kata tetap kata dan ada yang unbounded (bebas), yaitu padanan BSa tidak dalam satu tataran, umpamanya frase menjadi klausa. Istilah ini lebih popular dengan nama "penerjemahan kata demi kata, penerjemahan harfiah, dan penerjemahan bebas."

(1) Penerjemahan kata demi kata terungkap tataran kata.

God with them

Tuhan dengan dia

He likes rice-

Dia menyukai nasi

(2) Penerjemahan harfiah (literal) Penerjemahan ini ada di antara penerjemahan kata demi kata danpenerjemahan bebas. Biasanya penerjemahan ini dimilai dengan terjemahan kata demi kata, kemudian diadakan perubahanperubahan agar sesuai dengan tata bahasa $\mathrm{BSa}$, umpamanya memberikann kata-kata tambahan atau mengubah sreukturannya. He dropped his glasses kaca matanya terjatuh 
(3) Penerjemahan bebas

Penerjemahan ini cenderung bekerja pada tataran yang lebih tinggi, skala tataran padanan berubah-ubah. Penyesuaian kosakata ke dalam ungkapan idiomatis atau ungkapan berkolokasi merupakan ciri terjemahan bebas, umpamanya:

its raining cats and dogshujan turun lebat sekali

god with them Tuhan akan melindungi mereka

Di antara ketiga klasifikasi Catford pengkategorian berdasarkan tatanan (ranks) lebih aplikatif dalam praktik penerjemahan terutama bagi pemula.

Newmark (1988) mengklasifikasikan metode penerjemahan sebagai berikut.

1) Penerjemahan Kata demi Kata Penerjemahan kata demi kata sifatnya antarbaris (interlinear) dengan susunan kosakata BSa ada di bawahnya. Susunan kata dalam kalimat dipertahankan dan kosakatanya diterjemahkan satu demi satu dengan arti yang lebih umum, tanpa mempertimbangkan konteks. Penggunaan utama penerjemahan ini untuk memahami cara penyususnan (struktur) bahasa sumber atau untuk menafsirkan teks yang sukar sebagai proses awal penerjemahan.

I like rice

Saya menyukai nasi

The boy went to special schools (itu) anak pergi ke khusus sekolah (kata demi kata)

anak itu bersekolah di sekolah khusus

\section{2) Penerjemahan Harfiah}

Dalam penerjemahan ini, konstruksi tata bahasa di ubah sedekat mungkin dengan padannnya dalam BSa, tetapi kata-katanya diterjemahkan satu demi satu tanpa mempertimbangkan konteksnya. Hal ini dilakukan pada proses awal penerjemahan untuk menunjukkan masalah yang harus dipecahkan, contoh:

The thief was sent to the prison Pencuri itu dikirim ke penjara (harfiah) Pencuri itu dipenjara

\section{3) Penerjemahan Setia}

penerjemah ini berusaha menghasilkan makna kontekstual yang tepat pada teks asal dengan keterbatasan struktur tata bahasa BSa. Dalam penerjemahan ini, 
kosakata kultural dialihkan dan tingkat abnormalitas gramatikal dan leksikal (penyimpangan dari norma BSu) dipertahankan. Penerjemahan diusahakan agar betul-betul setia pada maksud dan realisasi teks dari penulis $\mathrm{BSu}$. Jadi, cara ini cenderung untuk sejauh mungkin mempertahankan atau setia pada isi dan bentuk Bsu, contoh;

Born without drims, he sent to special school

Lahir tanpa lengan lengan, dia dikirim ke sekolah khusus

Karena dilahirkan tanpa lengan, dia bersekolah di sekolah khusus

4) Penerjemahan Semantik penerjemahan ini berbeda dengan penerjemahan setia. Penerjemahan semantik lebih mempertimbangkan nilai estetika (bunyi yang indah dan alamiah) teks BSu yang menyesuaikan makna. Dalam terjemahan ini, kata-kata yang kurang penting diterjemahkan tidak dengan istilah kultural, tetapi dengan istilah fungsional atau yang netral secara kultural, terdapat penyesuaian-penyesuaian dengan khalayak pembaca. Penerjemahan ini lebih lentur dari penerjemahan setia dan memper- bolehkan kreativitas (tidak mengikuti $100 \%$ kesetiaan pada teks Bsu).

\section{5) Penerjemahan Adaptasi}

Penerjemahan ini adalah bentuk penerjemahan yang paling bebas dan terutama digunakan dalam penerjemahan drama dan komedi atau puisi. Tema dan karakter serta alur dipertahankan, tetapi kultur BSu diubah ke dalam kultur BSa dan teksnya ditulis kembali.

\section{6) Penerjemahan Bebas}

Penerjemahan bebas mereproduksi masalah (matter), tanpa cara (manner) atau isi tanpa bentuk asli. Biasanya terjemahan ini merupakan parafrase yang jauh lebih panjang dari bahasa aslinya, yang juga disebut "penerjemahan intrabahasa," yang sering berteletele, berlebihan, dan bahkan bukan terjemahan sama sekali.

7) Penerjemahan Idiomatik

Penerjemahan ini memproduksi pesan asli, tetapi cenderung mengubah nuansa arti dengan lebih banyak menggunakan bahasa sehari-hari (colloqualism) dan idiom yang tidak ada dalam teks BSu. 
8) Penerjemahan Komunikatif

Penerjemahan ini berusaha mengalihkan makna kontekstual yang tepat dari teks BSu sedemikian rupa, sehingga baik isi maupun bahasanya mudah diterima dan dapat dipahami oleh pembaca. Bagi Newmark, penerjemahan yang memenuhi tujuan penerjemahan hanyalah penerjemahan semantik dan komunikatif. Penerjemahan semantik digunakan untuk teks yang bersifat "ekspresif" dan penerjemahan komunikatif untuk teks yang bersifat "informatif" dan "vokatif."

\subsection{Hasil Penerjemahan}

Dalam proses pengalihan makna, kata, frase, klausa, kalimat, paragraf, dan teks digunakan metode tertentu sesuai dengan metode yang diuraikan di atas. Penerjemah akan selalu menilai hasil penerjemahannya. Penilaian dilakukan pada saat pelaksanaan penerjemahan atau pada terjemahan sementara. Dalam proses penilaian, penerjemah mungkin saja menilai keluaran (hasil terjemahan), tetapi juga menilai proses penerjemahannya itu sendiri.

Untuk menilai terjemahan diperlukan kriteria tertentu, yaitu adanya hal-hal yang harus dilihat secara umum dan secara khusus.
Sebetulnya kriteria penilaian sudah tersirat dalam pemilihan metode tertentu, yang sudah didefinisikan sejak awal dengan memperhitungkan berbagai faktor.

Menurut Catford, yang paling utama dalam penerjemahan adalah mendapatkan padanan terjemahan (translation equivalents). Padanan tersebut adalah suatu bentuk (teks atau bagian teks) yang dianggap sebagai padanan suatu bentuk tertentu. Pencariannya didasarkan pada otoritas penerjemah, yang diperoleh melalui prosedur formal yang disebut komutasi. Komutasi adalah suatu proses penggantian unsur teks BSu dengan melihat pengaruhnya pada teks BSa, misalnya:

My son is six - anak laki-laki saya berusia enam tahun

My daughter is six - anak perempuan saya berusia enam tahun

Suatu padanan mungkin saja bukan padanan formal (formal corespondence) untuk Bsu. Oleh karena itu, padanan suatu kata mungkin menjadi frase dan suatu frase mungkin menjadi kalimat.

Kriteria menurut Newmark, masalah penilaian penerjemahan termasuk ke dalam "kritik terjemahan," yang menjadi penghubung antarteori penerjemah dan praktik penerjemah. 
Dalam kaitan ini ada nilai absolut kecermatan dan kehematan selain nilai relatifnya.

Penilaian terhadap penerjemahan bukan hal yang mudah. Ada dua pendekatan yang dapat dilakukan, yaitu (a) Pendekatan fungsional berupa pendekatan umum yang berusaha apakah penerjemah berhasil usaha penerjemahannya dan di mana kekurangannya, pendekatan ini bersifat subjektif, (b) Pendekatan analitis, pendekatan ini bersifat rinci. Dalam kaitan ini, terjemahan yang jelek lebih mudah dikenali daripada penerjemahan yang bagus. Dalam penilaian ukurannya bersifat relatif, namun seseorang hendaknya berusaha, mendasarkan penilaian atas kriteria daripada norma. Terjemahan yang bagus memenuhi tujuannya, misalnya suatu teks informatif menyampaikan data secara wajar dari teks otoritatif atau ekspresif yang menghendaki terjemahan mempertimbangan pentingnya isi dan bentuk. Dalam penilaian terjemahan terdapat unsur ketidakpuasan dan subjektivitas, tetapi kenyataan ini tidak mengurangi petingnya atau manfaatnya kritik (penilaian) penerjemahan. $\mathrm{Hal}$ ini memerlukan alat untuk meningkatkan ukuran penerjemahan dan untuk mendapatkan lebih banyak kesempatan menjadi hakikat penerjemahan.

\section{Simpulan dan Saran}

\subsection{Simpulan}

Inti penerjemahan adalah melestarikan makna dari dua bahasa yang mencakup aspek semantik, pragmatik, dan tekstual. Aspek semantik mengacu pada makna denotatif, aspek pragmatik mengacu pada makna konotatif, dan aspek tekstual mengacu pada makna tekstual, yaitu pada bentuk wacana yang diproses melalui substansi, referensi, elipsis, dan metafora.

Proses penerjemahan menuntut bukan hanya menguasai dua bahasa, kedwibahasaan juga merupakan salah satu prasyarat. Penerjemah dituntut menggunakan pengetahuan bahasanya untuk membantu pembaca dan penulis dapat berkomunikasi dalam bahasa tulis. Prasyarat yang dituntut dari seorang penerjemah tidak selalu harus menguasai semua keterampilan dalam dua bahasa secara sama yang dituntut adalah kemampuan reseptif (membaca dalam Bsu) dan kemampuan produktif(menulis dalam BSa).

Untuk memahami suatu teks dituntut tidak hanya membaca umum (general reading), tetapi juga membaca cermat (clocer reading). Membaca umum bertujuan untuk memahami kata-kata baik dalam konteks teks maupun di luar konteks, dalam arti suatu kata hendaknya 
dilihat dari arti teknis, gaya bahasa, dan arti kiasan. Selain itu, dalam proses memahami teks yang akan diterjemahkan perlu ditentukan khalayak pembaca Bsu dan khalayak pembaca hasil terjemahan. Demikian juga saat membaca, penerjemah harus mencermati tingkat gaya bahasa, ragam bahasa resmi, bahasa formal, dan bahasa informal atau akrab.

Tujuan pokok penerjemahan adalah mengalihkan suatu teks BSu ke dalam Bsa, untuk sampai pada tujuan ini diperlukan cara dan teknik atau metode untuk mencapainya. Dalam hal ini Catford memopulerkan metode penerjemahannya yang terdiri dari word by word translation (penejemahan kata per kata), literary translation (penerjemahan harfiah), dan free translation (penerjemahan bebas).

\subsection{Saran}

Adapun saran-saran yang dikemukakan dalam tulisan ini adalah:

1) Penerjemah harus menguasai kiat penerjemahan, antara lain menguasai metode penerjemahan mana yang paling cocok dan yang paling dikuasainya, Dalam hal ini metode yang paling mudah digunakan adalah metode padanan menurut Catford, yaitu penerjemahan kata per kata, penerjemahan harfiah, dan penerjemahan bebas. Keterampilan menerjemahkan akan dikuasai apabila dilakukan dengan cara melatih diri dengan mencoba dan meralat terus-menerus. Dengan pengalaman menerjemahkan yang banyak, maka penerjernah akan terampil dan akan mempunyai kiat menerjemahkan yang makin lama makin baik.

2) Penerjemahan merupakan bentuk komunikasi dan penerjemah berperan sebagai komunikator. Oleh karena itu, komunikasi ini dapat dianggap sebagai suatu kegiatan yang menarik bila penerjemah dapat menampilkan terjemahannya dengan baik dan akan dibaca orang lain dengan memuaskan. Keberhasilan dalam kegiatan penerjemahan ini akan memberikan pengalaman berharga dan motivasi yang meningkat, serta percaya diri. 


\section{Pustaka Acuan}

Barnwell, K. 1984. Introduction to Semantiks and Translation. Horsley Green:

Summer Institute of Language.

Catford, J. 1965. A Linguistic Theory of Translation. Oxford: Oxford University Press.

Delisle, J. 1980. Translation An Interpretive Approach. Ottawa: University of Ottawa Press

Hatim, B. \& I. Mason. 1990. Discourse and The Translator. London: Longman Inc.

House, J. 1977. A Model for Translation Quality Assesment. Tubingen: TBL Verlag Gunter Naar.

Newmark, P. 1988. A Textbook of Translation. London: Prentice Hall International Ltd.

Newmark, P.1984. Approach to Translation. Oxford: Pergamon Press.

Weber, W. K. 1984. Training Translators and Conference Interpreters. Englewood Cliff: Prentice Hall Regent. 